\title{
Effects Of Working Environment And Motivation On The Employees' Performance In Enhancing The Quality Of Education In Malahayati Maritime Education And Training Center Of Aceh
}

\author{
Rafiqa Alfi Sari ${ }^{1}$, Yusrizal ${ }^{2}$, Nasir Usman $^{3}$ \\ $\left\{\right.$ lm_piecha@yahoo.co.id ${ }^{1}$,yusrizal_fkip@unsyiah.ac.id ${ }^{2}$,nasir@unsyiah.ac.id $\left.{ }^{3}\right\}$ \\ BP2IP Malahayati, Aceh Besar ${ }^{1}$, Indonesia FKIP Universitas Syiah Kuala, Indonesia ${ }^{23}$
}

\begin{abstract}
Working environment and motivation might give positive effects on an employee's performance, especially in enhancing the quality of education. Therefore, the objective of this research was to identify the effects of working environment and motivation on the employees' performance in enhancing the quality of education in Malahayati Maritime Education and Training Center (BP2IP) of Aceh. A mixed method was used in this research which was a population study with a number of 110 samples. The instruments used in this research were in form of scales related to working environment, motivation, and performance. The data obtained were then analyzed by using a multiple linear analysis with the following results. First, $\mathrm{H}_{1}$ shows that working environment positively affected the employees' performance with the coefficient $\mathrm{R}=$ 0.882 and $\mathrm{R}^{2}=0.777(77.7 \%)$ with the probability value (Sig.) $=0.000$ or $\mathrm{p}<0.05$. Moreover, $\mathrm{H}_{2}$ shows that motivation also positively affected the employees' performance with the coefficient $\mathrm{R}=0.941$ and $\mathrm{R}^{2}=0.886(88.6 \%)$ with the probability value (Sig.) $=$ 0.000 or $\mathrm{p}<0.05$. Finally, $\mathrm{H}_{3}$ shows that working environment and motivation positively affected the employees' performance with the coefficient $R=0.948$ and $R^{2}=0.900$ with the probability value (Sig.) $=0.000$ or $p<0.05$. Based on those results, it is suggested that BP2IP keeps motivating the employees and paying attention to any supporting factor in accordance with the policy of the institution in order to reach the institution's goals, enhance the employees' performance, and improve the quality of education provided by the institution.
\end{abstract}

Keywords: Working Environment, Motivation, Performance, Education Quality

\section{Introduction}

Human resources occupies an important position in order to achieve organizational goals that have been planned. Organization of business to be done in order to survive or progress is increasingly dependent on the management of human resources. The organization is a collection of people who have the same vision and mission to achieve the goals set. The most important factor in an organization is the human resources in accordance with the activities and the organization is run. Organizations realize that businesses manage their human resources does not stop on a presumption that people are important assets but to translate this belief into practice and human resource management procedures daily. 
One of the factors affecting the level of success of an organization is employee performance. Performance is the result of the quality and quantity of work that can be accomplished by an employee in carrying out duties in accordance with the duties and responsibilities given to him. Performance in the organization is the answer of the success or failure of the organization's goals have been set. Many factors determine the performance of employees, some of the factors that need to be observed is the work environment and motivation.

Malahayati Maritime Education dan Training Center (BP2IP) of Aceh is an educational institution that has the duty and responsibility to the nation to educate the nation's children a quality and responsive to advances Sailing in Indonesia. Main Tasks BP2IP Aceh is carrying out education and training in the field of shipping in the education and training of primary and secondary level according to standards and regulations applicable law. But besides that, in order to create professional sailors, excellence and ethics, education personnel and education staff are also an important factor in supporting the quality and take responsibility in improving the quality of learners who are responsive.

Educate and serve learners in supporting all the needs of learners not work and responsibility that is easy for employees. Many things have to be prepared from the education system, teaching professionals in the art, carers and professional trainers in the formation of character cadets, as well as training facilities that support education. All that is demanded of them that human resources as educators and education personnel should cooperate with each other and are both working extra in shaping and improving the capacity of cadets. One supporting factor for employees who can help the performance is by looking at the work environment and employee motivation itself.

Speaking about the work environment and motivation on the performance, there are some studies that have been done research, including Nurul (2018) which concluded that the working environment and motivation together positive effect on increasing the performance of employees of labor offices and Social Kab.Sleman making facilities improvement in the working environment department and the motivation of the employees still need to be improved for support the spirit of the employees to carry out work in accordance with the performance standards that have been made.

Besides, Armin (2017: 89) also revealed that the working environment and work motivation simultaneously significant effect on employee performance. This shows that the working environment and work motivation, will support the implementation of the person's work as expected.

Supported also by Yofanda (2015: 83) concluded that there is a positive influence motivation and work environment together on employee performance PDAM Kab. Sleman. So that the high motivation and adequate working environment and harmony can encourage employees to improve their performance becomes better.

From the above description, the purpose of this study are: "Effect of Working Environment and Motivation on The Employees' Performance In Enhancing The Quality of Education In Malahayati Maritime Education and Training Center of Aceh ".

\section{Methods}

This study aims to determine how much the work environment and motivation effect on employee performance in improving quality of education at BP2IP Malahayati Aceh. The 
research approach used is a combination approach (Mixed Methods) The research method is a combination of approaches in quantitative and qualitative research. It includes philosophical foundation, the use of quantitative and qualitative approaches, and combine both approaches in research.

The research subjects in this study were all employees at BP2IP Malahayati Aceh totaling 110 people, with the sample is Study Population. Processing of the data used is multiple linear analysis, this method is used to determine how much the work environment and motivation effect on employee performance in Improving Quality of education at BP2IP Malahayati Aceh

The variables examined in this study is the Work Environment variables (X1), Motivation (X2) and Employees performance (Y).

\section{Result and Discussion}

have an impact on the performance of employees who influence the agency / institution itself. The influence of the working environment are all things or elements that may affect directly or indirectly to the organization or agency that will give good or bad impact on employee performance. The results of this The influence of the working environment is not to be ruled out by the agency / institution because it will study are as follows:

a) Results Hypothesis 1 states that the working environment (X1) significantly affects performance (Y). This is evidenced by the value of the probability of 0000 with 0:05 alpha $(0.000<0.005)$ means that Ho refused and Ha accepted. Furthermore, linear regression analysis between the working environment $(\mathrm{X} 1)$ on the performance $(\mathrm{Y})$ shows the coefficient of $R=0882$, the coefficient of determination of $R^{2}=0.777$. The coefficient of determination $\left(\mathrm{R}^{2}\right)$ was used to determine the contribution of the independent variable on the dependent variable. To determine the contribution of independent variables on the dependent variable is the $\mathrm{R}$ Square multiplying by $100 \%$. Thus the magnitude of the contribution of the work environment on the performance of partial $=0.777 \times 100 \%=$ $77.7 \%$, which means that the work environment influence significantly by $77.7 \%$ of the performance of the employee in BP2IP Malahayati Aceh, while the other $22.3 \%$ is a variable. The results also supported by the results of research interviews with Head of the Financial Subdivision that BP2IP Malahayati Aceh already maximally and optimally in an effort to facilitate all the needs of employees in the work, both in terms of infrastructure, comfort and safety at work and continue efforts to increase healthy work environment. Deficiencies in an organization must belong but the effort to continue to optimize all the needs are the priority BP2IP Malahayati Aceh. This shows the better working environment, the better the performance of employees in improving the quality of education at BP2IP Malahayati Aceh. This shows the better work environment. The creation of a good working environment needs to be done in order to maintain the health and comfort and smoothness in the work. Especially aspects of lighting, air circulation, and the cleanliness of the environment need to be considered to improve the performance of teachers. Good working environment, conducive, comfortable, safe, clean, and calm will certainly lead or improve morale. Conversely, a poor working environment will degrade the performance of employees. To that end, the agency needs to pay attention and act wisely so that the working environment can provide a positive impact on the progress of the agency. The results of this study are consistent with the theory put forward by Diana Khairani Sofyan (2013) and Sari Andamdewi (2013), which states that the work 
environment affects the person's performance. Supported also by Andamdewi (2013: 211), that "the work environment allows employees to work more enthusiasm, so that their work is more satisfying."

b) Results Hypothesis 2 states that motivation (X2) significantly affects performance (Y). This is evidenced by the value of the probability of 0000 with $0: 05$ alpha $(0.000<0.005)$ means that Ho refused and Ha accepted. Furthermore, linear regression analysis between work motivation (X2) on the performance (Y) shows the coefficient of $\mathrm{R}=0.941$, coefficient of determination $\mathrm{R}^{2}=0.886$. The coefficient of determination $\left(\mathrm{R}^{2}\right)$ was used to determine the contribution of the independent variable on the dependent variable. To determine the contribution of independent variables on the dependent variable is the $\mathrm{R}$ Square multiplying by $100 \%$. With such a big contribution to the performance of work motivation is partially $=0.886 \times 100 \%=88.6 \%$, which means that motivation significantly influenced by $88.6 \%$ of the performance of the employee in BP2IP Malahayati Aceh, while the other $11.4 \%$ is a variable. The results of the above study is also supported by the results of interviews with Head of academic section, he said that we always support and give confidence to all employees in charge of the duties and responsibilities assigned. Monitor and evaluate each job each period in each section unit, so it would seem that the better the performance of anyone who's downhill and performance. The award may have to be optimized, so that the better performance. It shows the higher work motivation, the better the performance of employees in improving the quality of education at BP2IP Malahayati Aceh. This is in accordance with the opinion Suwardi \& Utomo (2011), which explains that "the proper motivation to be able to promote and develop the organization because employees will carry out duties in accordance with the field on the basis of consciousness." How the motivation starts from someone who consciously want to do the job vigorously and working in a better way. The work motivation can direct an action that is expected to be a means to an end. Therefore, employee motivation can be said to be a form of encouragement, which can give vigor to improve employee performance.

c) Results Hypothesis 3 states that an environmental work (X1) and motivation (X2) simultaneously affect a significant effect on performance (Y). The results of this study indicate that both the work environment and motivation to contribute to the performance of employees by $90 \%$. This means that the variable performance of employees affected by the work environment and work motivation by $90 \%$ and the remaining $10 \%$ is influenced by other variables outside two independent variables studied. The results also supported by the results of research interviews with the Head of BP2IP Aceh Malahayati stating that the working conditions and motivation largely determine the performance of employees. Head of BP2IP Malahayati Aceh also said that the satisfaction of learners is a priority BP2IP Malahayati Aceh. That is to say, in terms of creating satisfaction, the fundamental thing that must be met is the optimal service. In this case, BP2IP Malahayati Aceh relentless efforts and enhance all the needs of learners and employees in carrying out their duties. Learners is an asset that must be maintained and employees are as a guard and the finisher of assets, in other words the employee had a significant role in creating the appropriate learners with educational goals stipulated in Law No.20 of 2003, which aims to develop students' potentials to be a man of faith and fear of God Almighty, noble, healthy, knowledgeable, skilled, creative, independent, and become citizens of a democratic and accountable. As well as educational goals mentioned by UNESCO that in an effort to improve the quality of a nation, there is no other way except through the improvement of the quality of education. It can be concluded that BP2IP Malahayati Aceh through the clerks both instructors and non-instructors constantly working to improve the quality of 
education at BP2IP Malahayati Aceh, ranging from the means of funding infrastructure, work environment, safety and comfort of employee, employee satisfaction, professional educators and service improvement learners. Aspects of the working environment and motivation is the key element in the achievement of common goals are expected agency / institution. Agency / agencies will be able to run as expected if the work environment and work motivation can be met properly. The results support the idea (Ahmadi \& Uhbiyati, 2001), which states that the work environment affects a person's performance. This is because between man and the environment are interlinked. People affect the environment and so also affect one's environment. Thus, teachers and all school community needs to make the workplace a better environment, so as to motivate and increase the quantity and quality of the work.

\section{Conclusion}

The work environment and the motivation have a positive effect on employee performance in improving the quality of education at Balai Pendidikan dan Pelatihan Ilmu Pelayaran (BP2IP) Malahayati Aceh. It means that there needs the BP2IP Malahayati Aceh management for maintain the motivation of employees according to institution policy, give more attention and supporting to every aspect to employees need so that employees feel comfortable at work and are able to improve their performance on improving the quality of education at BP2IP Malahayati Aceh as well as better achieving the organization and maximally objective. 


\section{References}

[1] Ahmadi, Abu, Nur Uhbiyati. (2001). Ilmu Pendidikan. Jakarta: Rineka Cipta.

[2] A malia, Nurul Mutiara Risqi. (2018). Pengaruh Lingkungan Kerja dan Motivasi kerja terhadap kinerja pegawai di Dinas Tenaga Kerja dan Sosial Kabupaten Sleman. Jurnal.

[3] Andamdewi, Sari. (2013). Hubungan Lingkungan Kerja dengan Motivasi Kerja Pegawai Bagian Sekretariat Dinas Tenaga Kerja dan Transmigrasi Provinsi Sumatera Barat. Jurnal Administrasi Pendidikan, 1, 1, 211.

[4] Danang, Sunyoto. (2012). Manajemen Sumber Daya Manusia. Jakarta: PT Buku Seru.

[5] Dharma, Surya. (2012). Manajemen Kinerja: Falsafah, teori, dan Penerapannya. Yogyakarta: Pustaka Pelajar.

[6] Djamarah, Syaiful Bahri. (2011). Psikologi Belajar. Jakarta: Rineka Cipta.

[7] Kuswandi. (2004). Cara Mengukur Kepuasan Kerja. Jakarta : Elex Media Komputindo.

[8] Mangkunegara, Anwar Prabu. (2011). Manajemen Sumber Daya Manusia Perusahaan. Bandung: Remaja Rosdakarya.

[9] Muhamad Zainur Roziqin, (2010). Kepuasan Kerja, Malang: Averroes Press.

[10] Pratama, Yofanda Budi. (2015). Pengaruh Motivasi Kerja dan Lingkungan kerja terhadap Kinerja Karyawan pada Perusahaan Daerah Air Minum (PDAM) Kabupaten Sleman.

[11] Pratama, Armin. (2017). Pengaruh Lingkungan kerja dan Motivasi kerja terhadap kinerja pegawai Kantor BAPPEDA Kota Kendari.

[12] Sedarmayanti. (2009). Sumber Daya Manusia dan Produktivitas Kerja.Bandung: CV Mandar Maju.

[13] Suwardi \& Utomo, Joko. (2011). Pengaruh Motivasi Kerja, Kepuasan Kerja, dan Komitmen Organisasional terhadap Kinerja Pegawai. Jurnal Analisis Manajemen, 5, 1, 78.

[14] Sofyan, Diana Khairani. (2013). Pengaruh Lingkungan Kerja terhadap Kinerja Pegawai Bappeda. Malikussaleh Industrial Engineering Journal, 2, 1, 20.

[15] Sunyoto, Danang. (2013). Teori, Kuesioner, dan Analisis Data Sumber Daya Manusia (Praktik Penelitian) Cetakan Kedua. Yogyakarta : CAPS.

[16] Wulan, Lucky (2011). Analisis Pengaruh Motivasi Kerja dan Lingkungan Kerja terhadap Kinerja Karyawan. (Studi pada Dinas Perindustrian dan Perdagangan Kota Semarang). 